\title{
HUBUNGAN PENGETAHUAN TENTANG PERSONAL HYGIENE DENGAN PERILAKU PENCEGAHAN KEPUTIHAN PADA REMAJA PUTRI DI SMAN 15 SEMARANG
}

\author{
Aisyah Munawar ${ }^{*}$, Rose Nurhudhariani: ${ }^{* *}$ \\ STIKES KARYA HUSADA SEMARANG
}

Email : aisyah212593@gmail.com

\begin{abstract}
Abstrak
Latar Belakang: Kebersihan perseorangan atau Personal Hygiene merupakan suatu tindakan untuk memelihara kebersihan seseorang untuk menjaga kesejahteraan fisik dan psikis. Salah satu dampak dari kurangnya menjaga Personal Hygiene adalah terjadinya keputihan. Sebanyak $75 \%$ wanita di Indonesia pernah mengalami keputihan minimal satu kali dalam hidupnya dan $45 \%$ diantaranya mengalami keputihan sebanyak dua kali atau lebih. Di mana ditunjukkan jumlah yang dilayani dalam program kesehatan reproduksi terdapat $29,8 \%$ mengalami kejadian keputihan pada remaja putri. Tujuan: Mengetahui Hubungan Pengetahuan Tentang Personal Hygiene Dengan Perilaku Pencegahan Keputihan Pada Remaja Putri Di SMAN 15 Semarang. Metode: Jenis penelitian ini adalah kuantitatif dengan desain cross sectional. Popalasi dalam penelitian ini adalah remaja putri sebanyak 180 orang. Sampel dalam penelitian ini sebanyak 124 orang, dengan tehnik pengambilan sampel yanng digunakan adalah metode proportionate random sampling. Hasil: Remaja putri di SMAN 15 Semarang sebagian besar memiliki pengetahuan kurang sebanyak 100 responsen $(80,6 \%)$ dan pengetahuan cukup sebanyak 24 responden $(19,4 \%)$. Sementara perilaku remaja putri sebagian besar memiliki perilaku kurang baik sebanyak 97 responden $(72,8 \%)$ dan perilaku baik sebanyak 27 responden (21,8\%). Sehingga ada hubungan antara pengetahuan tentang Personal Hygiene dengan perilaku pencegahan keputihan. Saran: Pihak sekolah hendaknya memasukkan personal hygiene yang tepat ke dalam kurikulum pelajaran muatan lokal pendidikan kesehatan reproduksi atau sebagai materi pelajaran ekstra sehingga semua siswi mendapatkan pengetahuan yang sama sehingga diharapkan dapat menurunkan angka resiko terjadinya masalah kesehatan bagi remaja putri / para siswi.
\end{abstract}

Kata Kunci : Pengetahuan Personal Hygiene; Perilaku Pencegahan; Keputihan

Daftar Pustaka : 7 (2009-2014)

\section{RELATIONS WITH THE KNOWLEDGE OF PERSONAL HYGIENE BEHAVIOR PREVENTION WHITISH SMAN 15 SEMARANG}

\begin{abstract}
Background: Individual or Personal Hygiene Cleanliness is an act to maintain the cleanliness of a person to maintain physical and psychological wellbeing. One of the effects of lack of guard Personal Hygiene is the discharge. As many as $75 \%$ of women in Indonesia have experienced vaginal discharge at least once in their lives and $45 \%$ of them experienced vaginal discharge two times or
\end{abstract}


more. Where indicated amount served in reproductive health programs are $29.8 \%$ experienced vaginal discharge events in adolescent girls. Objective: To identify Relations Knowledge About Personal Hygiene With Discharge Prevention Behavior In Young Women In SMAN 15 Semarang. Metode Research: This type of research is quantitative with cross sectional design. Populasi in this study were young women of 180 people. The sample in this study as many as 124 people, with sampling technique used is proportionate random method sampling. Research Results: Results: Girls at SMAN 15 Semarang most have less knowledge as much as 100 responsen (80.6\%) and insufficient knowledge as much as 24 respondents (19.4\%). While the behavior of young women mostly had less good behavior as much as 97 respondents $(72.8 \%)$ and good behavior as much as 27 respondents $(21.8 \%)$. So that there is a relationship between knowledge about prevention behaviors Personal Hygiene with whitish. Suggestion: The school should include proper personal hygiene into the curriculum of local content or reproductive health education as an extra subject matter so that all students get the same knowledge which is expected to decrease the risk of health problems for girls / the girls.

Keywords : Knowledge Personal Hygiene, Preventive Behavior Whitish

Bibliography : 7 (2009-2014)

\section{Pendahuluan/Latar Belakang}

Kebersihan perseorangan atau Personal Hygiene merupakan suatu tindakan untuk memelihara kebersihan seseorang untuk menjaga kesejahteraan fisik dan psikis. Salah satu dampak dari kurangnya menjaga Personal Hygiene adaalah terjadinya ${ }^{[1]}$. Sebanyak $75 \%$ wanita di Indonesia pernah mengalami keputihan minimal satu kali dalam hidupnya dan $45 \%$ diantaranya mengalami keputihan sebanyak dua kali atau lebih ${ }^{[2]}$

Data statistik tahun 2011 jumlah remaja putri Jawa Tengah yaitu 2,9 juta berusia 15-24 tahun 45\% pernah mengalami keputihan. Dan pada tahun 2012 meningkat 3,1 juta jiwa. Jadi jumlah yang dilayani dalam program kesehatan reproduksi terdapat 89.815 jiwa, 29.8\% (26.797) mengalami kejadian keputihan pada remaja putri ${ }^{[2]}$.

Studi pendahuluan yang telah dilakukan di SMAN 15 Semarang, diperoleh data sebanyak 180 siswa remaja putri dari kelas XII terdiri dari 7 kelas, dari hasil wawancara pada guru Unit Kesehatan Sekolah (UKS) didapatkan data siswa yang mengeluh mengalami keluar cairan pada alat kelamin Dan kemudian dilakukan wawancara pada 10 siswa remaja putri SMAN 15 Semarang di dapatkan 7 siswa mengalami keputihan sedangkan 3 diantaranya sudah mengetahui cara membersihkan dan mengeringkan alat kelamin yang baik dan benar, baik sebelum menstruasi maupun sesudah menstruasi. 
Berdasarkan latar belakang dan fenomena di atas, maka peneliti tertarik untuk meneliti tentang "Hubungan Pengetahuan Tentang Personal Hygiene Dengan Perilaku Pencegahan Keputihan di SMAN 15 Semarang”.

Tujuan penelitian Mengetahui Hubungan Pengetahuan Tentang Personal Hygiene Dengan Perilaku Pencegahan Keputihan Pada Remaja Putri Di SMAN 15 Semarang.

\section{Tinjauan Teori}

Keputihan atau Fluora albus adalah cairan yang berlebihan dari vagina bukan merupakan darah ${ }^{[3]}$. Tanda-tanda keputihan normal adalah jika cairan yang keluar tidak terlalu kental, jernih, tidak berbau, warna putih atau kekuningan jika terkontaminasi oleh udara, tidak disertai rasa nyeri, dan tidak timbul rasa gatal yang berlebih. Tanda-tanda keputihan patologis antara lain cairan yang keluar sangat kental dan berubah warna, bau yang menyengat, jumlah yang berlebih dan menyebabkan rasa gatal, nyeri serta rasa sakit dan panas saat berkemih.

Personal Hygiene adalah tindakan untuk memelihara kebersihan dan kesehatan pada daerah kewanitaan untuk mencegah keputihan ${ }^{[1]}$. Perawatan personal hygiene simulai dari perawatan kulit kepala dan rambut sampai keseluruh tubuh khususnya genitalia. Manfaatnya meningkatkan kebersihan diri seseorang, memperbaiki personal hygiene seseorang yang kurang, pencegahan penyakit meningkatkan kepercayaab diri, dll ${ }^{[4]}$. Faktor yang mempengaruhi personal hygiene adalah, body image, status ekonomi sosial, pengetahuan, budaya, kebiasaan seseorang dan kondisi fisik ${ }^{[1]}$.

Perilaku manusia pada hakekatnya adalah suatu aktifitas dari manusia itu sendiri baik dapat diamati secara lnagsung maupun tidak langsung ${ }^{[5]}$. Faktor yang mempengaruhi perilaku adalah Predisposing Factor, Enabling factor, Reinforcing factor

Hipotesis alternatif (Ha) ada hubungan pengetahuan tentang personal Hygiene terhadap Perilaku Pencegahan Keputihan di SMAN 15 Semarang.

\section{Metode Penelitian}

Jenis penelitian ini adalah penelitian Kuantitatif dengan tujuan untuk menguji hipotesis yang telah ditetapkan ${ }^{[6]}$. Desain penelitian yang digunakan adalah metode Cross Sectional. Populasi dalam penelitian ini adalah siswi putri kelas XII di SMAN 15 Semarang 
yang berjumlah 180 siswi dengan sampel 124 responden. Penelitian ini menggunakan metode Proportionate Random Sampling yaitu suatu tehnik penetapan sampel secara acak tanpa memperhatikan strata yang ada dalam anggota populasi ${ }^{[5]}$.

Variabel yang akan di ukur adalah Pengetahuan tentang personal hygiene dan Perilaku pencegahan keputihan, tehnik pengambilan data menggunakan kuesioner, Analisis Univariat meliputi data pengetahuan tentang personal hygiene, dan data perilaku pencegahan keputihan. Dalam analisis ini menghasilkan distribusi frekuensi dan presentase dari tiap variabel, Analisis bivariat untuk melihat hubungan dari tiap variabel independent dan dependent,dengan menggunakan uji statistik chi-square dengan tingkat kemaknaan.

\section{Hasil Penelitian}

1. Analisa Univariat

a. pengetahuan

Tabel 4.1. Distribusi frekuensi pengetahuan Personal Hygiene pada remaja putri kelas XII di SMAN 15 Semarang.

\begin{tabular}{lll}
\hline Pengetahuan & Frekuensi & Persentase \\
\hline Baik & 0 & $0 \%$ \\
Cukup & 24 & $19,4 \%$ \\
Kurang & 100 & $80,6 \%$ \\
\hline Total & 124 & 100.0
\end{tabular}

Tabel 4.1 di atas dapat diketahui bahwa remaja putri di SMAN 15 Semarang sebagian kecil mempunyai pengetahuan cukup sebanyak 24 responden $(19,4 \%)$ dan sebagian besar mempunyai pengetahuan kurang sebanyak 100 responden $(80,6 \%)$.

b. perilaku

Tabel 4.2. Distribusi frekuensi perilaku pencegahan keputihan pada remaja putri kelas XII di SMAN 15 Semarang.

\begin{tabular}{lll}
\hline Perilaku & Frekuensi & Persentase \\
\hline Baik & 27 & $21,8 \%$ \\
Kurang baik & 97 & $78,2 \%$ \\
\hline Total & 124 & 100.0
\end{tabular}

Tabel 4.2 di atas dapat diketahui bahwa remaja putri di SMAN 15 Semarang sebagian kecil mempunyai perilaku baik sebanyak 27 responden $(21,8 \%)$ dan sebagian besar mempunyai perilaku kurang baik sebanyak 97 responden $(72,8 \%)$.

2. Analisa bivariat 
Tabel 4.3. Tabel silang antara tingkat pengetahuan personal hygiene dengan perilaku pencegahan keputihan pada remaja putri kelas XII di SMAN 15 Semarang.

\begin{tabular}{lccccccc}
\hline \multirow{2}{*}{ Pengetahuan } & \multicolumn{4}{c}{ Perilaku } & \multicolumn{2}{c}{ Jumlah } & \multirow{2}{*}{ p_value } \\
\cline { 2 - 7 } & \multicolumn{2}{c}{ Baik } & \multicolumn{2}{c}{ Kurang baik } & \multicolumn{2}{c}{} & \\
\cline { 2 - 7 } & $\mathrm{N}$ & $\%$ & $\mathrm{~N}$ & $\%$ & $\mathrm{~N}$ & $\%$ & \\
\hline Cukup & 10 & $8,1 \%$ & 14 & $11,3 \%$ & 24 & $100,0 \%$ & 0,019 \\
Kurang & 17 & $13,7 \%$ & 83 & $66,9 \%$ & 100 & $100,0 \%$ & \\
\hline Total & 27 & $21,8 \%$ & 97 & $78,2 \%$ & 124 & $100,0 \%$ & \\
\hline
\end{tabular}

Tabel silang di atas dapat diketahui bahwa remaja putri di SMAN 15 Semarang sebagian besar memiliki pengetahuan kurang baik dan perilaku kurang baik sebanyak 83 responden $(66,9 \%)$.

Berdasarkan hasil penelitian, kemudian dilakukan analisa data dengan menggunakan perhitungan secara statistik melalui uji Chi square dengan derajat kepercayaan (95\%) dengan kebebasan $(\mathrm{df})=1$ setelah data diolah ternyata terdapat 0 sel $(0 \%)$ yang mempunyai nilai harapan $<5$, sehingga di analisis menggunakan Chi square dengan tingkat probabilitas $\alpha$ : 0,05. Dari hasil olah data didapatkan nilai Continuity Correlation sebesar 5,541 dengan $\mathrm{p}$ value sebesar $0,019<0,05$, maka berdasarkan kriteria penolakan Ho dapat dinyatakan Hipotesa (Ho) ditolak dan Hipotesa (Ha) diterima berarti ada hubungan yang bermakna antara pengetahuan personal hygiene dengan perilaku pencegahan keputihan pada remaja kelas XII di SMAN 15 Semarang.

\section{Pembahasan}

1. Analisa Univariat

a. Pengetahun

Remaja putri yang memiliki pengetahuan yang kurang baik dikarenakan kurangnya informasi baik dari pihak sekolah maupun dari tenaga kesehatan dan kurangnya pengetahuan tentang personal hygiene. Kemudian dapat juga berdampak karena kebiasaan seseorang/individu dalam melakukan perawatan diri, pengalaman, media massa, kondisi lingkungan sekolah, pengaruh teman dan ketidaksiapan guru untuk memberikan pendidikan kesehatan reproduksi, serta kurangnya kesadaran remaja untuk memeriksakan kesehatan reproduksi. Keputihan pada kalangan remaja merupakan masalah yang tidak diperhatikan akibatnya kebanyakan remaja tidak mengetahui secara persis apa yang harus dilakukan saat mengalami keputihan. Remaja juga cendurung risih atau tidak mampu memberikan informasi yang memadai mengenai alat reproduksi dan proses reproduksi ${ }^{[7]}$. 
Terbukti jumlah remaja putri dengan pengetahuan kurang sebanyak 100 (80,6\%), jumlah ini sangat jauh dengan jumlah remaja putri dengan pengetahuan yang cukup sebanyak $24(19,4 \%)$.

Hasil peneltian ini berbanding terbalik dengan penelitian Fadhila Arint Prasetya (2013) tentang hubungan tingkat pengetahuan dan sikap remaja putri tentang kebersihan genitalia dengan kejadian keputihan di SMA PGRI 1 Kendal. Hasil penelitian dari 114 responden yang tidak mengalami keputihan sebanyak 103 (71,5\%) dikarenakan mayoritas remaja putri memiliki pengetahuan dan sikap yang baik tentang kebersihan genital.

b. Perilaku

Remaja putri yang memiliki perilaku yang kurang baik, dikarenakan adanya faktor predisposisi yaitu pengetahuan yang kurang mengenai personal hygiene dalam mencegah keputihan, dan faktor pemungkin yaitu kurangnya sarana dan prasarana/fasilitas mengenai pendidikan kesehatan reproduksi di sekolah serta faktor penguatnya pengalaman pribadi yaitu kebiasaan individu dalam melakukan perawatan diri yang kurang baik, pengaruh teman, pengaruh media massa mengenai berbagai macam pembersih vagina, pembinaan dari tenaga kesehatan mengenai kesehatan reproduksi yang belum pernah dilaksanakan disekolah serta belum adanya pengambilan keputusan dalam diri remaja untuk memeriksakan kesehatan reproduksinya, dan dari pihak sekolah belum ada pengambilan keputusan mengenai pendidikan kesehatan reproduksi ${ }^{[7]}$.

Hasil penelitian diketahui bahwa remaja putri di SMAN 15 Semarang sebagian besar mempunyai perilaku kurang baik sebanyak 97 responden $(72,8 \%)$ dan perilaku baik sebanyak 27 responden $(21,8 \%)$. Hal ini menunjukkan bahwa remaja di SMAN 15 Semarang belum mempunyai tanggung jawab dalam menjaga kebersihan diri. Hal tersebut dilakukan karena remaja putri belum mengetahui dampak dan akibat yang akan dialami apabila tidak merawat organ genitalianya dengan baik.

Hasil penelitian diketahui bahwa remaja putri di SMAN 15 Semarang sebagian besar mempunyai perilaku kurang baik sebanyak 97 responden $(72,8 \%)$. Hal ini menunjukkan bahwa remaja di SMAN 15 Semarang belum mempunyai tanggung jawab dalam menjaga kebersihan diri. Hal tersebut dilakukan karena remaja putri belum mengetahui dampak dan akibat yang akan dialami apabila tidak merawat organ genitalianya dengan baik.

2. Analisa bivariat

Hasil penelitian diketahui bahwa remaja putri di SMAN 15 Semarang sebagian besar memiliki pengetahuan kurang baik dan perilaku kurang baik sebanyak 83 responden $(66,9 \%)$. 
Ada hubungan yang bermakna antara tingkat pengetahuan personal hygiene dengan perilaku pencegahan keputihan pada remaja putri kelas XII di SMAN 15 Semarang.

Remaja putri yang mempunyai pengetahuan kurang baik sebagian besar memiliki perilaku kurang baik dikarenakan kuranngnya pengetahuan remaja mengenai personal hygiene dan kurangnya kesadaran remaja putri untuk memeriksakan kesehatan reproduksi, serta kurang berpartisifasinya tenaga kesehatan untuk melakukan pembinaan kesehatan disekolah. Dan juga didukung dengan pengaruh media massa yang memasarkan berbagai macam produk pembersih vagina, kondisi lingkungan sekolah, pengaruh teman serta ketidaksiapan guru untuk memberikan pendidikan kesehatan reproduksi, Sehingga yang terjadi adalah munculnya reaksi atau respon yang negatif antara lain merasa malu, cemas, sedih. Sebagian besar wanita merasa masih tabu untuk membicarakan hal itu diakibatkan minimnya pengetahuan tentang apa itu keputihan, dan bagaimana mencegah keputihan. Berdasakan kondisi tersebut, seharusnya remaja putri secara dini mengetahui tentang personal hygiene, keputihan ${ }^{[7]}$. dan bagaimana mencegah keputihan

Remaja putri yang mempunyai pengetahuan kurang baik 17 orang tetapi berperilaku baik, hal ini karena adanya faktor predisposisi seperti pengetahuan yang dimiliki serta kesadaran dari individu tersebut, kemudian faktor pemungkinnya terpenuhinya sarana prasarana dalam menjaga kesehatan reproduksinya seperti biaya yang terjangkau sehingga memudahkan mendapatkan pelayanan, serta adanya faktor penguatnya yaitu acuan dari petugas kesehatan, misalkan memiliki keluarga yang berprofesi kesehatan dan juga pengaruh media massa, pengalaman pribadi serta pengambilan keputusan dari individu tersebut ${ }^{[5]}$.

Hasil penelitian ini sejalan dengan penelitian Sumini (2014) tentang Hubungan antara perilaku personal hygiene dengan keputihan pada siswi MTs Tsamratul Huda Desa Tergo Kec. Dawe Kab. Kudus. Hasil penelitian penelitian remaja putri didapatkan dari 20 responden (63,89\%), 20 responden $(55,56 \%)$ mempunyai perilaku personal hygiene dalam kategori baik dengan menjaga kebersihan dan memperhatikan penggunaan pakaian.

\section{Kesimpulan}

1. Remaja putri di SMAN 15 Semarang sebagian besar mempunyai pengetahuan kurang.

2. Remaja putri di SMAN 15 Semarang sebagian besar mempunyai perilaku kurang.

3. Ada hubungan yang bermakna antara pengetahuan personal hygiene dengan perilaku pencegahan keputihan pada remaja kelas XII di SMAN 15 Semarang. 


\section{Saran}

1. Bagi SMAN 15 Semarang

Pihak sekolah hendaknya memasukkan personal hygiene yang tepat ke dalam kurikulum pelajaran muatan lokal pendidikan kesehatan reproduksi atau sebagai materi pelajaran ekstra sehingga semua siswi mendapatkan pengetahuan yang sama sehingga diharapkan dapat menurunkan angka resiko terjadinya masalah kesehatan bagi remaja putri / para siswi.

2. Remaja

Meningkatkan pengetahuannya terkait menjaga kebersihan diri terutama area perineal secara teratur baik saat di rumah, di sekolah maupun dimana saja yang bisa didapat dari keluarga, kelompok / teman, maupun media masa. Serta mengajak yang lain untuk berperilaku sehat dan supaya tidak terjadi masalah kesehatan reproduksi pada remaja putri.

3. Tenaga Kesehatan

Hasil penelitian ini dapat memberikan masukan untuk meningkatkan pengetahuan personal hygiene dengan perilaku pencegahan keputihan pada remaja putri dengan cara memberikan penyuluhan tentang personal hygiene dan keputihan serta penyebaran leaflet sehingga pengetahuan remaja akan meningkat tentang personal hygiene dalam mencegah keputihan

4. Institusi Pendidikan

Hasil penelitian ini diharapkan dapat digunakan sebagai bahan kajian pustaka bagi kemajuan ilmu pengetahuan tentang personal hygiene dan pencegahan keputihan sehingga dapat menghasilkan penelitian sejenis yang lebih baik lagi.

5. Peneliti

Bagi peneliti selanjutnya perlu dilakukan penelitian lebih lanjut untuk membuktikan dan mengetahui faktor lain yang dapat mempengaruhi pengetahuan personal hygiene dan peilaku pencegahan keputihan.

\section{Daftar Pustaka}

[1] Laila, 2011. Buku Pintar Menstruasi. Yogyakarta: Buku Biru

[2] Profil Dinas Kesehatan Profinsi. 2013. Jawa Tengah

[3] Sibagariang, E, E et, al. 2012. Kesehatan Reproduksi Wanita. Jakarta: Trans Info.

[4] Manan, EL. 2013. Kamus Cerdik Kesehatan Wanita. Yogyakarta: Buku Biru

[5] Notoatmodjo, S. 2012. Metodologi Penelitian Kesehatan. Jakarta: Rineka Cipta 
[5] Sugiyono, 2011. Metode Penelitian Pendidikan Bandung: Alfabeta

[7] Notoatmodjo, S. 2010. Kesehatan Masyarakat Ilmu dan Seni. Jakarta: Rineka Cipta. 